\title{
CONCENTRATION OF HEAVY METALS IN TISSUES OF GREEN TURTLES (CHELONIA MYDAS) SAMPLED IN THE CANANÉIA ESTUARY, BRAZIL
}

\author{
Edison Barbieri
}

Instituto de Pesca - APTA - SAA/SP

(Av. Prof. Besnard s/n, 11990-000, Caixa Postal 61, Cananéia, SP, Brasil)

E-mail: edisonbarbieri@yahoo.com.br

\begin{abstract}
Thirty specimens (15 adults and 15 juveniles) of Chelonia mydas found in the Cananéia estuary in the state of São Paulo on the southeastern Brazilian coast between January 2005 and September 2006, were analyzed The concentrations of $\mathrm{Cd}, \mathrm{Cu}, \mathrm{Pb}, \mathrm{Mn}$ and $\mathrm{Ni}$ in liver and kidney samples of adult and juvenile green turtles were determined by Flame Atomic Absorption Spectrophotometry. The average $\mathrm{Cd}$ concentration found in adult livers $\left(0.57 \mu \mathrm{g} . \mathrm{g}^{-1}\right)$ was significantly higher than that in juveniles $\left(0.279 \mu \mathrm{g} \cdot \mathrm{g}^{-1}\right)$. Cu concentrations were significantly higher in the liver than in the kidney, and significantly higher in adults $\left(39.9 \mu \mathrm{g} \cdot \mathrm{g}^{-1}\right)$ than in juveniles $\left(20.7 \mu \mathrm{g} \cdot \mathrm{g}^{-1}\right)$. Average $\mathrm{Mn}$ concentrations in liver and kidney did not differ between adults $\left(4.32\right.$ and $\left.4.17 \mu \mathrm{g} \cdot \mathrm{g}^{-1}\right)$ and juveniles

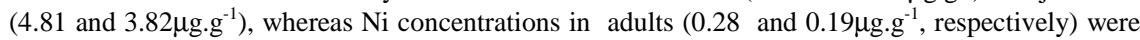
significantly higher than in juveniles $\left(0.13\right.$ and $0.089 \mu \mathrm{g} \cdot \mathrm{g}^{-1}$, respectively). $\mathrm{Pb}$ concentrations in liver were significantly higher in adults $\left(0.37 \mu \mathrm{g} \cdot \mathrm{g}^{-1}\right)$ than in juveniles $\left(0.06 \mu \mathrm{g} \cdot \mathrm{g}^{-1}\right)$. The concentrations of essential trace elements in Chelonia mydas were generally comparable to values reported in other, similar studies. With respect to non-essential metals $(\mathrm{Cd}, \mathrm{Pb}$ and $\mathrm{Ni})$, Chelonia mydas presented lower values than those reported for their northern Atlantic counterparts.
\end{abstract}

\section{RESUMO}

Analisou-se 30 espécimes (15 adultos e 15 juvenis) de Chelonia mydas encontradas no estuário de Cananéia, Estado de São Paulo, região sudeste, durante o período de janeiro de 2005 a setembro de 2006. Foram determinados no fígado e rins de adultos e juvenis de C. mydas os seguintes metais: $\mathrm{Cd}$, $\mathrm{Cu}, \mathrm{Pb}, \mathrm{Mn}$ e $\mathrm{Ni}$, através de Espectrofotometria de Absorção Atômica. Verificou-se que as concentrações médias de Cd no fígado de adultos $\left(0,957 \mu \mathrm{g} \cdot \mathrm{g}^{-1}\right)$ foram significativamente diferentes em relação a dos juvenis $\left(0,279 \mu \mathrm{g} \cdot \mathrm{g}^{-1}\right)$. As concentrações médias de $\mathrm{Cu}$ no fígado de $C$. mydas foram diferentes em relação ao rim. Houve diferença também entre os fígados de adultos $\left(39,9 \mu \mathrm{g} \cdot \mathrm{g}^{-1}\right)$ e juvenis $\left(20,7 \mu \mathrm{g} \cdot \mathrm{g}^{-1}\right)$. Os valores médios de Mn encontrados no fígado e rim não diferiram entre adultos $\left(4,32\right.$ e $\left.4,17 \mu \mathrm{g} \cdot \mathrm{g}^{-1}\right)$ e juvenis $\left(4,81\right.$ e $\left.3,82 \mu \mathrm{g} \cdot \mathrm{g}^{-1}\right)$. Já as médias das concentrações de Ni no fígado e rins de adultos $\left(0,28 \mathrm{e} 0,19 \mu \mathrm{g} \cdot \mathrm{g}^{-1}\right)$ foram diferentes das dos juvenis $\left(0,13 \mathrm{e} 0,089 \mu \mathrm{\mu g} \cdot \mathrm{g}^{-1}\right)$. Entretanto, as concentrações de $\mathrm{Pb}$ no fígado foram significativamente mais altas em adultos $\left(0,37 \mu \mathrm{g} \cdot \mathrm{g}^{-1}\right)$ do que nos juvenis $\left(0,06 \mu \mathrm{g} \cdot \mathrm{g}^{-1}\right)$. As concentrações dos elementos traços essenciais em $C$. mydas foram comparáveis aos valores registrados em outros estudos. Quanto aos metais não essenciais $(\mathrm{Cd}, \mathrm{Pb}$ e $\mathrm{Ni}), C$. mydas apresentou uma menor concentração em relação às registradas para o Atlântico Norte.

Descriptors: Green turtle, Heavy metal, Chelonia mydas, Concentration, Liver, Kidney, Sea turtle Descritores: Tartaruga verde, Metal pesado, Chelonia mydas, Concentração, Fígado, Rim, Tartaruga marinha.

\section{INTRODUCTION}

Sea turtles offer a number of particular advantages as indicators of heavy metal pollution (LAM et al., 2004). They have been exhaustively studied and as they feed at the upper trophic levels of oceanic ecosystems can provide information on the extent of contamination throughout the food chain. Metal levels in sea turtles may give a better picture of hazards to humans than do measurements taken in the physical environment, such as those taken in plants or invertebrates (ANAN et al., 2002).
Pelagic species have higher levels of mercury and cadmium than most inshore species, and Nicholson and Osborn (1983) concluded that the levels were natural rather than a consequence of pollution, reasoning that pollution by heavy metals would be more likely to affect inshore species (MUIRHEAD; FURNESS, 1988). Similarly, high levels of metals occur in some sea turtles where pollution effects are reasonably assumed to be minimal (ANAN et al., 2002). However, atmospheric transport of metals and selective uptake or storage by marine organisms could cause increases in pelagic ecosystems (BRYAN, 1984; BARBIERI et al., 2007). 
Sea turtles are excellent subjects for the examination of heavy metal concentrations because they are longlived, feed at various trophic levels, and at varying distances from land. Due to their high conservation status, there is increasing interest in these endangered species throughout the world (LAM et al., 2004). Several recent reports have documented a decline in sea turtle populations, which have been attributed to pollution, including marine debris, tar balls and plastics (TOMAS et al., 2002), and toxic contaminants, including trace elements and heavy metals (SAKAI et al., 2000; ANAN et al., 2002). It is conceivable that metals may play a role in reducing sea turtle populations, and the most frequently monitored elements have been lead, mercury and cadmium.

Previous monitoring studies of heavy metals in sea turtles have been undertaken in Japanese, Chinese, European and American coastal waters (SAKAI et al., 2000; TOMAS et al., 2002; LAM et al., 2004); however, no such work has been carried out on the Brazilian coast. In the present study measurements of cadmium, copper, nickel, manganese and lead levels were made in tissues of green turtles (Chelonia mydas) that feed in Cananéia estuary, Brazil, where local pollution by heavy metals is presumably negligible or non-existent. The specific objective of this paper was to compare the concentration of heavy metals in adults and juveniles of green turtles, a study quite new in Brazil.

\section{Materials AND Methods}

Collection and storage of turtles. Cananéia estuary is situated in the state of São Paulo, on the southeastern Brazilian coast and is an important place for the feeding and juvenile development of green turtles. The fresh tissues of 30 specimens ( 15 adults, 15 juveniles) recently dead found along the estuary between January 2005 and September 2006, were analyzed Immediately after collection, the tissues were brought to the Laboratory of Ecotoxicology of the Universidade Federal de Sergipe and stored frozen until analyzed. After biometric measurements and weighing, the animals were dissected and the kidneys and livers were removed.

Reagents. All reagents were of analytical grade. High purity water (Millipore Milli-Q System) was used throughout. The stock solutions of metals (1000 mg.g $\mathrm{g}^{-1}$ ) were obtained by dissolving the appropriate salts of the corresponding metals. Concentrated nitric acid (65\%) and perchloric acid $(69 \%)$ were used to digest the samples. Standard Reference Material (SRM) of oyster tissues (No. $1566 \mathrm{~b})$ from the National Institute of Standard Technology (NIST) was used to validate the method.

Sample pretreatment and microwave digestion. The samples were dried in a furnace equipped with an air circulation system at $60^{\circ} \mathrm{C}$ for $48 \mathrm{~h}$, and homogenized using a porcelain mortar. Then they were dissolved by microwave digestion (Anton Paar Multiwave, A-8054 Graz, Austria-Europe) using a system of rotors with six positions (6MF100). Approximately $400 \mathrm{mg}$ of dry sample was treated with a mixture 2:1 $\mathrm{HNO}_{3}: \mathrm{H}_{2} \mathrm{O}_{2}$ and placed into the TMF vessel of the Parr reactor. The vessel was closed and heated for $20 \mathrm{~min}$ in the microwave oven. After cooling, the reactor was opened. Then the entire resultant solution was quantitatively transferred to a $50 \mathrm{ml}$ volumetric flask, and the remainder made up to $50 \mathrm{ml}$ with ultrapure water. The solution was stored at $4^{\circ} \mathrm{C}$ in polyethylene bottles until it was analyzed.

$\mathrm{Cd}, \mathrm{Cu}, \mathrm{Ni}, \mathrm{Mn}$ and $\mathrm{Pb}$ were determined using a Flame Atomic Absorption Spectrophotometry (AA-6800, Shimadzu Co. Ltd, Japan) equipped with background correction BCG-D2. The instrumental adjustments made were those recommended by the manufacturer's manual.

All element concentrations $\left(\mu \mathrm{g} \cdot \mathrm{g}^{-1}\right)$ in organs were expressed on a dry weight basis. As an analytical quality control, standards of oyster tissue were analyzed using the same procedure. The results obtained were in good agreement with the certified values as shown in Table 1.

Table 1. Observed and certified values $\left(\mu \mathrm{g} \cdot \mathrm{g}^{-1}\right)$ of concentration of elements in SRM (oyster tissues No. 1566b) shown as means \pm S.D. Each value is the average of three separate digestions.

\begin{tabular}{cccc}
\hline \hline Element & Observed value & Certified value & Recovery $(\%)$ \\
\hline $\mathrm{Cd}$ & $2.50 \pm 0.04$ & $2.49 \pm 0.05$ & 99.6 \\
$\mathrm{Cu}$ & $70.0 \pm 1.2$ & $70.7 \pm 1.4$ & 101 \\
$\mathrm{Ni}$ & $1.20 \pm 0.18$ & $1.17 \pm 0.05$ & 97.5 \\
$\mathrm{Mn}$ & $18.4 \pm 1.1$ & $18.5 \pm 0.3$ & 100.5 \\
$\mathrm{~Pb}$ & $0.310 \pm 0.080$ & $0.308 \pm 0.005$ & 99.3 \\
\hline
\end{tabular}


The average distribution of heavy metals in the green turtles was assessed using analysis of variance (ANOVA). The comparisons were made with Tukey`s multiple comparison test $(p<0.05)$, in the kidneys and liver of adults and juveniles respectively.

\section{RESULTS}

Concentrations of the elements analyzed in the livers and kidneys of adult and juvenile green turtles are presented in Table 2. Cadmium levels were significantly higher in the kidneys than in the liver for all samples. There was no statistical difference in cadmium concentration between the kidneys of adults and juveniles $(\mathrm{F}=3.35 ; \mathrm{P}=0.06)$. However, cadmium concentration averages in the liver of juveniles were significantly lower than those in adults $(\mathrm{F}=4.99 ; \mathrm{P}=$ 0.03) (Fig. 1A). Copper concentrations were significantly different between liver and kidney $(\mathrm{F}=$ 32.36; $\mathrm{P}<0.001$ ), and there was a significant difference in liver concentrations between adults and juveniles $(F=45.48 ; P<0.001)$ (Fig. 1B). As regards manganese, its concentrations in liver and kidney did not differ between adults and juveniles $(\mathrm{F}=0.05 ; \mathrm{P}=$ $0.75)$, and the averages in the liver were not significantly different from those in the kidney $(\mathrm{F}=$ 0.025; $\mathrm{P}=0.75$ ) (Fig. 1C). On the other hand, nickel concentrations in the liver of adults were significantly higher than in those of juveniles $(\mathrm{F}=24.15 ; \mathrm{P}=$ 0.001 ), and in the liver they were significantly different from those in the kidney $(\mathrm{F}=23.75$; $\mathrm{P}=$ 0.0001) (Fig. 1D). The results of the lead concentrations measurements in the liver and kidney were significantly higher in adults than in juveniles ( $\mathrm{F}$ $=4.76 ; \mathrm{P}=0.035)$, and the averages were not significantly different in either organ $(\mathrm{F}=0.75 ; \mathrm{P}=$ 0.45) (Fig. 1E).

Table 2. Values of concentrations of elements (mean \pm S.D, $\mu \mathrm{g} . \mathrm{g}^{-1}$ ) in the liver and kidneys of green turtles found dead in an estuary on the Atlantic coast of Brazil $(n=30)$.

\begin{tabular}{lcc}
\hline \hline & \multicolumn{2}{c}{ Organs } \\
\hline $\begin{array}{l}\text { Elements } \\
\text { Cadmium }\end{array}$ & Liver & Kidney \\
Adult & $0.957 \pm 0.31$ & $2.18 \pm 0.27$ \\
Juvenile & $0.279 \pm 0.14$ & $1.00 \pm 0.32$ \\
Copper & & \\
Adult & $39.9 \pm 1.94$ & $13.72 \pm 1.15$ \\
Juvenile & $20.7 \pm 2.46$ & $12.55 \pm 1.04$ \\
Manganese & & \\
Adult & $4.32 \pm 0.71$ & $4.17 \pm 0.86$ \\
Juvenile & $4.81 \pm 0.90$ & $3.82 \pm 0.73$ \\
Nickel & & \\
Adult & $0.28 \pm 0.08$ & $0.19 \pm 0.02$ \\
Juvenile & $0.13 \pm 0.04$ & $0.089 \pm 0.01$ \\
\hline
\end{tabular}

\section{DisCUSSION}

The concentrations of essential trace elements in green turtles were generally comparable to the values reported in others studies. As regards nonessential metals, some marine turtle species can accumulate considerable body burdens of $\mathrm{Cd}$ and/or $\mathrm{Pb}$. In this study, green turtles had smaller values than those reported for their northern Atlantic, Japanese and Chinese counterparts; however, I cannot determine if this is due to smaller concentrations of these metals in the South Atlantic, or to dietary differences between populations from different feeding grounds. Studies of the sea turtles provide the best means of assessing the impact of metal pollution due to fishing weights and has focused attention on the quantities of metals being discarded in the seas. For this reason, there is a need for monitoring efforts to help conserve these animals. Green turtles are highly mobile, and the migration distance between feeding and breeding sites can be from hundreds to thousands of kilometers (PLOTKIN, 2003). It is conceivable that contaminants found in the tissues of marine turtles can be attributed to chemical pollutants present in both their feeding range and breeding sites (LAM et al., 2004).

In this study the concentration of cadmium was higher in kidneys than in liver. According to Furness and Monaghan (1987), cadmium concentration is always highest in the kidney, where it is thought that a specific metal-binding protein (metallothionein) generally renders the metal harmless. Cadmium can cause damage to the vertebrate kidney but there is little evidence to suggest that the cadmium levels are high enough to cause harm to sea turtles. However, Caurant et al. (1999) reported that kidneys of green turtles and hawksbills indicated pathological features. Cadmium levels in other tissues tend to be much lower, except when a turtle has recently ingested a large amount of the metal. In this case the level in the liver may be equal to or exceed that in the kidney, giving an indication of recent acute exposure (SCHEUHAMMER, 1987; FURNESS, 1994; AGUIRRE et al., 1994).

Cadmium is extremely poisonous and can have various deleterious effects on fish, shrimp, and wildlife in general (BARBIERI, 2007; BARBIERI, 2009). In this study the concentration of cadmium was greater in adults than in juveniles and this fact may be due to the fact that cadmium is known to accumulate with increasing age (FURNESS, 1994). Anan et al. (2002) observed similar kidney damage in green turtles and hawksbills at cadmium levels comparable to those found in loggerheads (Caretta caretta). The cadmium concentrations reported here are consistent with data on other sea turtle species from locations elsewhere. 

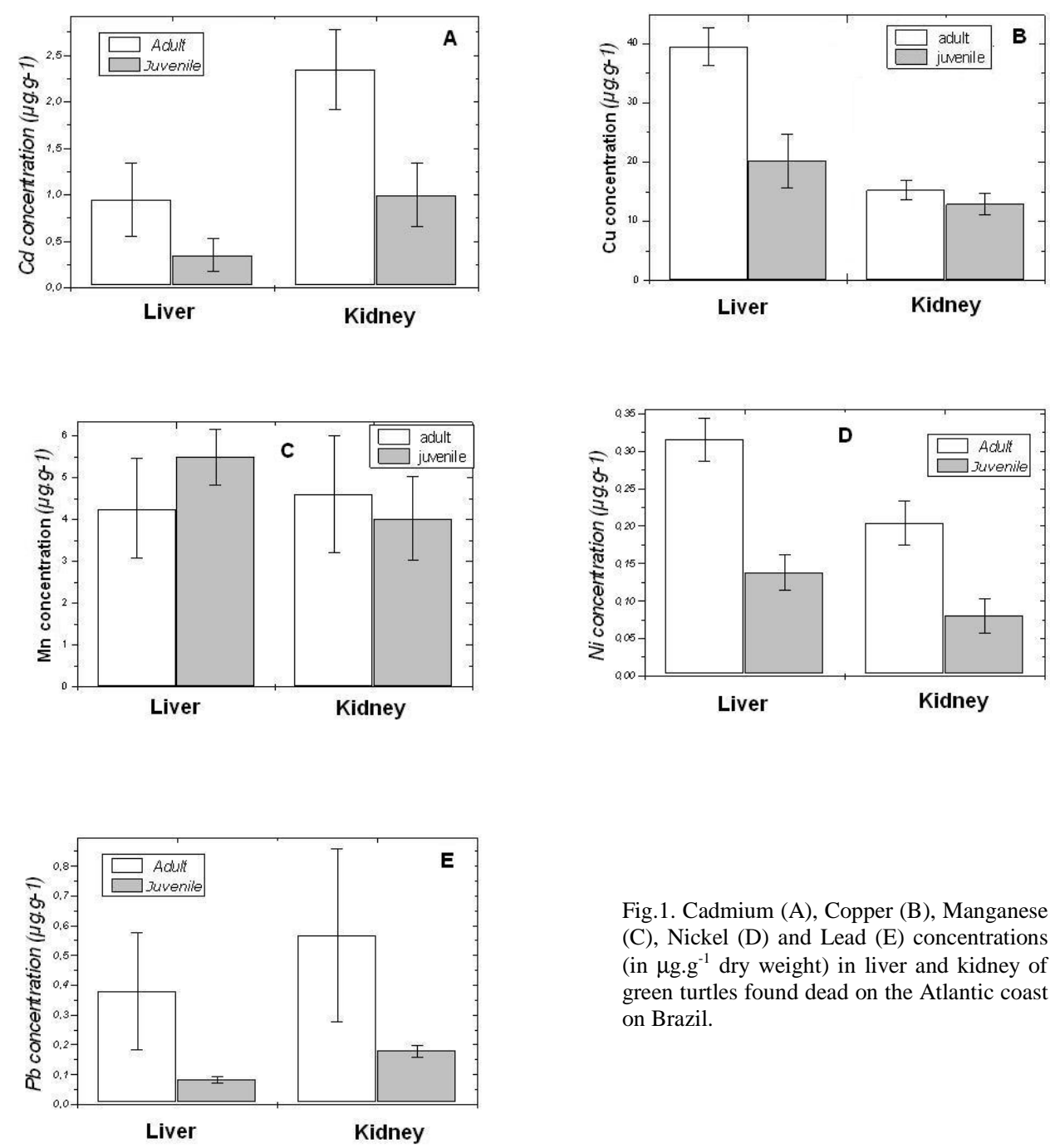

In the present study significant differences seem to exist in the levels of the essential trace elements copper and manganese between the liver and kidney of the Chelonia mydas. Similar levels of copper and manganese have been detected in other sea turtle species from different parts of the world (TOMAS et al., 2002). The significance of the differences found between liver and kidney for copper are difficult to assess. Exceptionally high levels of copper have been found in a few loggerhead specimens. However, such high copper levels occur in other species of sea turtles without any accompanying signs of toxic effects (LAM et al., 2004). Levels were highest for manganese, followed by copper and

cadmium. These values represent current levels found in green turtles in Chinese waters (LAM et al., 2004). Since both metals can be classified as essential, the concordance with other studies indicates a close metabolic regulation of copper and manganese.

The copper levels found in Chelonia mydas in this study are higher than those that were found in hawksbill turtles (Eretmochelys imbricata) by Anan et al. (2002). High copper levels in sea turtles, including the green turtle of the present study, are likely to have arisen from species-specific bioaccumulation, and unlikely to reflect pollution or higher natural backgrounds of copper in their habitats (SAKAI et al., 2000). 
Exposure of aquatic organisms to nickelcontaminated sediments may result in a variety of adverse effects, including mortality, reduction in growth rate, and avoidance reactions. The toxicity of nickel increases in the presence of copper, synergism may, therefore, be a factor that modifies the toxicity of the former substance. Whereas the bioconcentration of nickel has been observed in a variety of organisms (particularly in annelids), biomagnification is not a significant concern in aquatic environments (CCREM 1987).

Significant differences seem to exist in the levels of nickel between liver and kidney and juveniles and adults of Brazilian Chelonia mydas. The differences between adults and juveniles for nickel, were probably due to accumulation with age (SUSAN et al. 2006). Similar levels of nickel have been detected in other sea turtle species from different parts of the world (SAKAI et al., 2000; LAM et al., 2004). The significance of the differences found between liver and kidney for nickel is also difficult to evaluate. Exceptionally high levels of nickel have been found in a few specimens of seabirds (BARBIERI et al., 2007). However, such high nickel levels occur in other species of sea turtle without any signs of toxic effects (GORDON; POPLE, 1998; GODLEY et al., 1999; GARDNER et al., 2006).

Lead is a multitargeted toxicant, and inorganic lead is carcinogenic in animals (ATSDR 1997). Blood lead levels, haematocrit, and enzyme assays can be used to measure the exposure of animals to lead (O'HALLORAN et al., 1989; FURNESS, 1994). Comparatively little lead is deposited in oceans such as the south Atlantic, whereas relatively high lead deposition fluxes are encountered in areas of the northern hemisphere close to anthropogenic sources (BURGER; GOCHFELD, 2000). Low lead concentrations have been reported for a range of sea turtle species sampled from oceanic or remote locations (AGUIRRE et al., 1994; GODLEY et al., 1999). Since the effects of anthropogenic emissions of lead to the environment would likely be greatest closer to the source of pollution, one would predict that coastal and inshore marine biota would carry the highest lead burdens, and several workers have found somewhat elevated lead concentrations in species from such environments (TURNER et al., 1978; LEE et al., 1989; LOCK et al., 1992). In the specimens analyzed in the present study, adults exhibited the highest lead levels. This fact may occur because lead, as well as cadmium, is known to accumulate with age (FURNESS, 1994; BURGER; GOCHFELD, 2000).

In conclusion, $\mathrm{Cu}$ and $\mathrm{Ni}$ examined in Brazilian green turtles showed high concentrations in the liver, while $\mathrm{Cd}$ was high in the kidney. The concentrations of $\mathrm{Mn}$ and $\mathrm{Pb}$ were relatively high in the liver and kidney. Copper concentrations in the liver of green adult sea turtles were apparently higher than those reported in cetaceans and seabirds, suggesting that turtles may have specific mechanisms which lead to higher $\mathrm{Cu}$ accumulation in the liver. The concentrations of $\mathrm{Cd}, \mathrm{Ni}$ and $\mathrm{Pb}$ were relatively higher in adults than in juveniles, the accumulation probably being due to age. Studies of turtles provide the best means of assessing the impact of metal pollution due to fishing weights and have focused attention on the quantities of metals being discarded in the seas.

\section{ACKNOWLEDGMENTS}

I am grateful to Dr. David Pike (University of Sydney) for comments on an earlier version of this paper.

\section{REFERENCES}

AGUIRRE, A. A.; BALAZS, G. H.; ZIMMERMAN, B.; GALEY, F. D. Organic contaminants and trace metals in the tissues of green turtles (Chelonia mydas) afflicted with fibropapillomas in the Hawaiian Islands. Mar. Pollut. Bull., v. .28, p. 109-114, 1994.

ANAN, Y.; KUNITO, T.; SAKAI, H.; TANABE, S. Subcellular distribution of trace elements in the liver of sea turtle. Mar. Pollut. Bull., v. 45, p. 224-229, 2002.

ATSDR. (Agency for Toxic Substances and Disease Registry) ATSDR's Toxicological profiles on CDROM.

BARBIERI, E. Use of oxygen consumption and ammonium excretion to evaluate the sublethal toxicity of cadmium and zinc on Litopenaeus schmitti (Burkenroad, 1936, Crustacea). Wat. Environ. Res., v. 79, n. 5, p. 123-129, 2007.

BARBIERI, E. Effects of zinc and cadmium on oxygen consumption and ammonium excretion in pink shrimp (Farfantepenaeus paulensis, Pérez-Farfante, 1967, Crustacea). Ecotoxicology, v. 18, n. 3, p.312-318, 2009.

BARBIERI, E.; GARCIA, C. A. B.; PASSOS, E. A.; ARAGÃO, K. A. S.; ALVES, J. P. H. A. Heavy metal concentration in tissues of Puffinus gravis sampled on the Brazilian coast. Rev. Brasil. Ornitol., v. 15, n. 1, p. 69-72, 2007. 1997.

BURGER, J.; GOCHFELD, M. Metal levels in eggs of common terns (Sterna hirundo) in New Jersey: temporal trends from 1971 to 2002. Environ. Research., v. 94, p. 336-343, 2000.

BRYAN, G. W. Pollution due to heavy metals and their compounds. pp. 1289-1431. In: KINNE, O. (Ed). Marine ecology. London: Wiley Interscience, 1984.

CAURANT, F.; BUSTAMANTE, P.; BORDES, A.; MIRAMAND, P. Bioaccumulation of cadmium, copper and zinc in some tissues of three species of marine turtles stranded along the French Atlantic coasts. Mar. Pollut. Bull., v.38, p. 1085-1091, 1999.

CCREM (Canadian Council of Resource and Environment Ministers). Canadian water quality guidelines. Prepared by the Task Force on Water Quality Guidelines. 1987. 
FURNESS, R. W. Birds as monitors of pollutants. In FURNESS, R. W.; GREENWOOD, J. J. D. (Ed.). Birds as monitors of environmental change. London: Chapman \& Hall, 1994. p 356.

FURNESS, R. W.; MONAGHAN, P. (Ed.). Seabird ecology. New York: Chapman \& Hall, 1987. 164 p.

GARDNER, S. C.; FITZGERALD, S. L.; VARGAS, B. A.; RODRÍGUEZ, L. M. Heavy metal accumulation in four species of sea turtles from the Baja California peninsula, Mexico. BioMetals, v.19, p.91-99, 2006.

GODLEY, B. J.; THOMPSON, D. R.; FURNESS, R. W. Do heavy metal concentrations pose a threat to marine turtles from the Mediterranean Sea? Mar. Pollut. Bull. v. 38, p.497-502, 1999.

GORDON, A. N.; POPLE, A. R. Trace metal concentrations in livers and kidneys of sea turtles from south-eastern Queensland, Australia. Mar. Freshwater Res., v. 49, p.409-414, 1998.

HONDA, K. J. E.; MARCOVECCHIO, E.; KAN, S.; TATSUKAWA, R.; OGI, H. Metal concentration in pelagic seabirds from the north Pacific ocean. Archives of Environ. Contamin. Toxicol., v.19, p.704-711, 1990.

LAM, J. C. W.; TANABE, S.; CHAN, S. K. F.; YUEN, E. K. W.; LAM, M. H. W.; LAM, P. K. S. Trace element residues in tissues of green turtles ( Chelonia mydas) from South China Waters. Mar. Pollut. Bull., v.48, p.164-192, 2004.

LEE, D. P.; HONDA, K.; TATSUKAWAM, R.; WON, P. O. Distribution and residue level of mercury, cadmium and lead in Korean birds. Bull. environ. Contamin. Toxicol., v.43, p. 550-555, 1989.

LOCK, J. W.; THOMPSON, D. R.; FURNESS, R. W.; BARTLE, J. A. Metal concentrations in seabirds of the New Zealand region. Environ. Pollut., v.75, p.289- 300, 1992.

MUIRHEAD, S. J.; FURNESS, R. W. Heavy metals concentration in the tissues of seabirds from Gough Island, South Atlantic Ocean. Mar. Pollut. Bull., v.19, p.278-283, 1988 .
NICHOLSON, J. K.; OSBORN, D. Kidney lesions in pelagic seabirds with high tissue levels of cadmium and mercury. Jour. Zool., Lond., v. 200, p. 99-118, 1983.

O'HALLORAN, J.; MYERS, A. A.; DUGGAN, P. F. Some sub-lethal effects of lead on mute swan Cygnus olor. J. Zool., Lond.,. v. 218, p. 627-632, 1989.

PLOTKIN, P. Adult migration and habitat use. In: LUTZ, P. L.; MUSICK, J. A.; WYNEKEN, J. (Ed.). The biology of sea turtles, v. 2. Boca Raton, FLA.: CRC Press, 2003. p. 225-242.

SAKAI, H.; SAEKI, K.; ICHIHASHI, H.; SUGANUMA, H.; TANABE, S.; TATSUKAWA, R. Arsenic accumulation in three species of sea turtle. BioMetals, v.13, p.241250, 2000.

SCHEUHAMMER, A. M. The chronic toxicity of aluminium, cadmium, mercury and lead in birds: a review. Environ. Pollut. v. 46A, p. 263-296, 1987.

SUSAN, C. G.; FITZGERALD, S. L.; VARGAS, B. A.; RODRÍGUEZ, L. M. Heavy metal accumulation in four species of sea turtles from the Baja California peninsula, Mexico. BioMetals, v. 19, p. 91-99, 2006.

TOMAS, J.; GUITART, R.; MATEO, R.; RAGA, J. A. Marine debris ingestion in loggerhead sea turtles Caretta caretta from the Western Mediterranean. Mar. Pollut. Bull., v. 44, p. 211-216, 2002.

TURNER, J.C.; SOLLY, S. R. B; MOI-KRIJNEN, J. C. M. SHANKS, V. Organochlorine, fluorine and heavy-metal levels in some birds from New Zealand estuaries. N. Z. Jl. Sci., v.21, p. $99-102,1978$.

(Manuscript received 31 March 2008; revised 25 March 2009; accepted 03 April 2009) 